\title{
The Utilization of Digital Books by Ministry of Education and Culture for Improving Children's Literacy
}

\author{
Febyasti Davela Ramadini \\ Communication Department \\ Universitas Indonesia \\ Jakarta, Indonesia \\ febidavelar@gmail.com
}

\begin{abstract}
Nowadays, digitalization is such a popular thing in professional and academic life. Ministry of Education and Culture take the advantages of this phenomenon by creating digital based education method. This method provides many features, one of that is digital book. This research identifies the utilization of digital books by Ministry of Education and Culture for improving children's literacy. Digital books are one of the features of "Rumah Belajar" application made by Ministry of Education and Culture. Digital books utilization could help many ones, such as teachers in school. This research use qualitative approach with published documents and interview with user of "Rumah Belajar" as data. The results of this study show numbers of benefits that's provided by this digital book. Teachers use digital books of "Rumah Belajar" for teaching in class. Thus, digital books of "Rumah Belajar" can improve children's literacy through the benefits it provides.
\end{abstract}

Keywords—digital books, literacy, "Rumah Belajar”

\section{INTRODUCTION}

Technology whose function is to facilitate human work, also influences the academic and professional fields. The book is one that gets influence from the growth of technology. Digital books were born and support the publication of books to be read by the wider community. integrity of a book hasn't changed much over the past five centuries, books have remained ubiquitous and inconspicuous, that is, words printed on sheets of paper tied together with two covers [1]. Even though the picture of a book that is in the minds of humans still refers to a collection of paper wrapped in a cover, digital books remain a trend in society. The popularity of digital books is increasingly rising and attracting attention. Digital book users are very diverse, from students to scientists.

Digital books or electronic books are not only useful for readers, but also have benefits for writers, librarians, publishers, or anyone involved in the use of digital books. This has led to the increasing popularity of digital books in the community. The difference in characteristics between books in the classic format and digital books is very significant. Digital books make it easier for readers to read wherever and whenever, while in terms of costs are also efficient. Effectiveness and efficiency are the main objectives of digital books. Although there are groups who prefer to read books directly in physical form, rather than reading digital books.

As with other agencies, the government also uses digital books as a tool to attract the attention of the public. As conducted by the Ministry of Education and Culture which developed its book into a digital book that can be accessed free of charge by the people of Indonesia. The Ministry of Education and Culture through the Center for Information and Communication Technology has created a "Rumah Belajar" website and application (learning.kemdikbud.go.id) as a free digital learning tool that can be accessed by the public. One of the services available at Rumah Belajar is digital books. Digital books are divided into two types, namely digital books and non-learning lessons. Digital textbooks consist of school textbooks such as mathematics, physics, history, and so on. Meanwhile, non-textbooks are books of folklore or fiction that are expected to increase the reading interest of Indonesian children.

\section{THEORETICAL REVIEW}

\section{A. Benefits of Digital Books}

The presence of digital books brings many benefits to the individuals who use them. Digital book users are not only readers, but also publishers, writers, and libraries. All parties feel the benefits of digital books so that they become a series of reading processes that are more effective and efficient. There are four benefits provided by digital books. According to Rao (2004), the benefits of digital books are divided into five when viewed from its users, namely for readers, libraries, publishers, writers, and for increasing national literacy. The following discussion of the benefits of the digital book [2]. However, this research will only discuss benefits for readers / users and in increasing national literacy. Benefits of digital books for readers, i.e.

- The reader access to the desired book is wider. Downloading books from the internet is faster and easier than going to a bookstore or library. Online or online bookstores provide 24-hour service without interruption and can be read without printing.

- Readers will find it easier to find keywords, definitions, and parts of books that you want to read. Readers only type in the keywords you want to find and then the digital book will present portions of the book that contain these keywords,

- Book display is more flexible to be customized such as lighting, font size, and so on. 
- Digital books are easier to carry wherever the reader goes. The reader only needs to carry one device that contains tens or even hundreds of digital books stored in the device's memory or available in a virtual bookcase that is accessed by the network.

- Multimedia facilities are also provided by digital books to support readers understanding and engaging in books. These facilities include sound, music, graphics, images, or videos as well as features provided by external applications that can be integrated with digital books.

- $\mathrm{f}$. The nature of digital books that are environmentally friendly also benefits the reader. Digital books don't need paper sheets made of wood.

In addition to the benefits for those who use digital books, digital books also provide benefits in improving national education and literacy standards. One step that can be done is that the National Library can work with publishers to produce books at a lower cost. Then the books can be given free to the public. Although the cost required is cheaper, the reach that can be achieved by the National Library can be wider because it uses the internet network.

\section{B. Children's Literacy}

According to Hutinger et al, literacy is a social process, a psychological process, and a linguistic process [3]. Literacy is a thing that binds individuals in their daily lives because literacy is related to social life, individual psychologists, and linguistics. Literacy is very important in the lives of people of all age groups, even children need literacy in their development. Literacy is like spoken language obtained through the active senses of children and data obtained from the results of their interactions with adults [3].

Teale et al formulated a conclusion about the development of children's literacy, namely as the ability to listen, speak, read, and write develop simultaneously and not interrelated; the function of reading and writing is an important part of learning literacy; early behavior of children is a legitimate phase and is not an initial part of literacy; This behavior and conceptualization develops in various ways towards conventional literacy [4].

The development of technology supports literacy activities in the community. Literacy support activities are easier to do with advanced technology. Interactive technology allows the senses of children to work more actively and in the end can better understand the writing that is read. Multimedia applications related to literacy can be beneficial for children with low literacy skills such as phonological awareness, print concepts, comprehension, and reading not word for word [3].

\section{RESEARCH METHOD}

This study uses a qualitative approach, qualitative research is research that means exploring and understanding the views of individuals or groups on social problems [5]. The qualitative approach procedure is collecting data, analyzing, interpreting, and making reports. The research data were analyzed inductively, that is by discussing the details and then extending to the main discussion. This study uses journals and articles related to this research topic as data and uses data from interviews with users of digital books "Rumah Belajar". One of the users of the digital book "Rumah Belajar" is a teacher named Roro Martiningsih, a teacher at SMP Muhammadiyah 1 Surabaya. Researchers interviewed these participants because the participant was one of the promoters of the "Learning House" at his school and in Surabaya.

\section{RESUlT AND DISCUSSION}

After conducting an interview with one of the Muhammadiyah 1 Surabaya Middle School teachers, Roro Martiningsih, there were several findings related to the use of digital books in the "Rumah Belajar" program. "Rumah Belajar" is a program of the Ministry of Education and Culture that is actively used by Indonesian schools, especially schools in the participant city, Surabaya. A total of 301 public elementary schools in Surabaya are involved in the "Learning House" program, while 62 public junior high schools in Surabaya are involved. Involved in the "Learning House" program are mandatory activities launched by the Surabaya Education Office. This involvement is shown by the training of elementary and junior high school teachers to use the "Rumah Belajar" application in classroom learning activities. In addition, the "Rumah Belajar" program appoints a number of selected teachers to become ambassadors of the "Rumah Belajar" which aims to promote the "Rumah Belajar" to schools in the city.

Features that can be used in the "Rumah Belajar" application are electronic school books, virtual laboratories, virtual classes, question banks, media catalogs in animation, images, presentations, videos, and audio. Digital books or Electronic School Books available in the application "Rumah Belajar" are the result of integration with the website buku.kemdikbud.go.id, which website is managed by the Curriculum and Book Center, Ministry of Education and Culture. Meanwhile, the application "Rumah Belajar" is an application managed by the Center for Information and Communication Technology, Ministry of Education and Culture. The books available on the website include textbooks for elementary, middle and high school students; specialization textbooks for grade 10-12 high school students; and non-textbooks. The books are intended for students and teachers who teach.

The books available in the "Rumah Belajar" application can be read using two methods, which are read online or by downloading them. Display digital books on the application "Rumah Belajar" interesting and easy to use. Users can use the autoflip feature when reading to proceed to the next page of the book automatically. Users can also choose the page or section that they want to read easily. If the user does not have the device to access the diigtal book, the user can also print it.

Digital books have many benefits for the parties involved. One of the parties involved in the presence of the digital book "Rumah Belajar" is the user [2]. The benefits in using digital books "Rumah Belajar" by users are:

- Users or readers of digital books "Rumah Belajar" can download books available easily and without distance and time limit. The digital book "Rumah Belajar" can be used by all people who are scattered in various regions for 24 hours. Teachers and students can use it in the classroom, or wherever they want as long as they can connect to the internet.

- The digital book display application "Rumah Belajar" looks interesting and easy to operate. In addition, users 
or readers can also type the keywords you want to search. This is in accordance with the benefits of digital books that can facilitate the reader in finding what is desired by the reader.

- Digital books "Learning House" can be enlarged (zoom in) and reduced (zoom out) according to the needs of readers. All can be customized according to the wishes of the reader. This is different from the use of conventional books whose appearance has been determined by publishers or authors so that readers cannot adjust it as needed.

- The number of digital books in the application "Rumah Belajar" numbered in the tens or even hundreds. This makes it easier for readers because readers don't need to carry dozens of physical books if they want to read them. The reader only needs to access the learn.kemdikbud.go.id page. then there are dozens of books that can be enjoyed by readers online.

- Not only digital books, but there are other features that can support the understanding of readers or users of the application "Rumah Belajar". These features are in the form of videos, images, and even there is a feature "Space Exploration" that allows users to see phenomena that occur in space according to the location of the phenomenon.

- Although readers can download digital books in the "Rumah Belajar" application and print them, users will feel the benefits of digital books more when users read them digitally, not conventionally. This makes users reluctant to print books and in the end will give a positive output, which is to reduce paper usage.

Apart from the phenomenon of digitizing books, reading activities are very important activities to become a habit for children. Reading and writing are important parts in literacy learning [4]. As an institution responsible for education in Indonesia, the Ministry of Education and Culture produces curricula and books that can support children's literacy. Through various agencies underneath, the Ministry of Education and Culture produces textbooks and non-learning books and assesses and tests the feasibility of books to be published in schools. This is to present quality readings for children.

In accordance, multimedia applications related to literacy can be beneficial for children with low literacy, the Ministry of Education and Culture develops a "Learning House" program to be able to support children's literacy learning in Indonesia [4]. Through features in the "Learning House", the Ministry of Education and Culture seeks to create interesting learning facilities for children. The children's response to the "Learning House" application is also good. This can be seen in the videos of the reports of the teachers who participated in the "Rumah Belajar" training, which is the response of students in schools in Surabaya that looked positive and enthusiastic. The teachers also feel the benefits because they can use the "Learning House" as a medium for student learning.

\section{CONCLUSION}

The use of the digital book "Rumah Belajar" by the Ministry of Education and Culture in improving the literacy of Indonesian children is very good. The benefits of digital books can be felt directly by its users, namely teachers and students. The digital book "Rumah Belajar" can be a learning medium that will support children's literacy learning. Digital books available at "Rumah Belajar" are divided into several types, namely textbooks, specialization books, and non-textbooks. The benefits of Kemendikbud's "Rumah Belajar" digital books can be accessed without space and time restrictions, makes it easy to find parts of the book, its appearance can be customized as needed, easy to carry anywhere, more attractive because it is supported by other multimedia, and environmentally friendly. Utilization of the digital book "Rumah Belajar" is done by using the help of the teacher when in the classroom. Teachers are given training using the "Learning House" application so they can use it when teaching and learning activities in the classroom.

\section{REFERENCES}

[1] Hean Tat Keh, Evolution of the book publishing industry: Structural changes and strategic implications. Journal of Management History. 4(2): 104-123, 1998

[2] Siriginidi Subba Rao, Electronic book technologies: an overview of the present situation. Library Review. 53(7): 363-371, 2004.

[3] Patricia Hutinger, Linda Robinson, Carol Schneider, and Joyce Johanson, The Early Childhood InteractiveTechnology Literacy Curriculum Project:A Final Report. United States Department of Education: Illinois, 2002.

[4] William H. Teale, Elfrieda H. Hiebert, Edward A. Chittenden, Assessing Young Children's Literacy Development. The Reading Teacher: 772:777, 1987.

[5] Creswell, John W, Research Design : Qualitative, Quantitative, and. Mixed Methods Approaches. Newbury Park: Sage Publications, 2009. 